\title{
IAHS: a brief history of hydrology
}

\author{
Dan Rosbjerg ${ }^{1}$ and John Rodda ${ }^{2}$ \\ ${ }^{1}$ Department of Environmental Engineering, Technical University of Denmark, \\ Bygningstorvet, 2800 Kongens Lyngby, Denmark \\ ${ }^{2}$ Centre for Ecology \& Hydrology, Maclean Building, Benson Lane, Crowmarsh Gifford, \\ Wallingford, Oxfordshire, OX10 8BB, UK \\ Correspondence: Dan Rosbjerg (daro@env.dtu.dk)
}

Received: 26 October 2018 - Accepted: 26 November 2018 - Published: 16 April 2019

\begin{abstract}
After describing the hydrological cycle and defining hydrology in the introduction, the early historical development of hydrology is briefly presented in the second section. Then the incorporation of hydrology within the IUGG and the subsequent development of the association are described chronologically. This description is organized into five sections corresponding to five different periods, focused on the scientific and organizational development of the association during each period. Finally, in the conclusions, the present state of the association is discussed together with an outlook for the future.
\end{abstract}

\section{Introduction: what is hydrology?}

Determining what happens to the rain when it hits the ground eventually leads to the concept of the hydrological cycle, which is the natural sequence through which water passes from vapour in the atmosphere to precipitation that on land separates into evaporation, transpiration and runoff to the sea, equalling net sea evaporation. Hydrology is the science that deals with the processes governing the depletion and replenishment of the water resources of the land areas of the Earth, and treats the various phases of the hydrological cycle. In a slightly extended wording, hydrology can be described as the science that deals with the waters above and below the land surface of the Earth, their occurrence, circulation and distribution, in both time and space, their biological, chemical and physical properties, and their reaction with the environment, including their relation to human beings.

When considering the central role of the hydrological cycle in the definition, hydrology is primarily thought of as a branch of geophysics, in the same way as oceanography and meteorology. In other contexts, where the emphasis is on water utilization, hydrology encompasses the broader concept of water resources, including societal relations, engineering and land use. This raises the argument over whether hydrology is a pure or applied science.
The many diverse forms and occurrences of water on the Earth, and the many different ways of utilizing water resources, gave rise to the concept of the hydrological sciences. These sciences (or branches of hydrology) include surface water, groundwater, water-related erosion and sediment transport, snow and ice, water quality, eco-hydrology, landatmosphere interactions, catchment hydrology, flood forecasting, and water resources management. The list is endless and might also include the water on the Moon, Mars and other bodies in the solar system.

The development of hydrology in the 19th century was dominated by the emerging needs for river engineering, water supply and urban drainage. In the 20th century, hydrology gradually moved away from hydraulics and established its own scientific community. This went hand in hand with developments in data collection, which are indispensable for insight into the hydrological processes.

Towards the end of the last century, the growing awareness of the environment influenced hydrology such that environmental questions became a main driver for the development of the science. Pollution abatement, water resources assessment and nature conservation were, and still are, central issues. Today, other keywords are climate change impact, integrated approaches in catchment management, sustainable river basin management and uncertainty reduction in hydrological forecasting and prediction. 


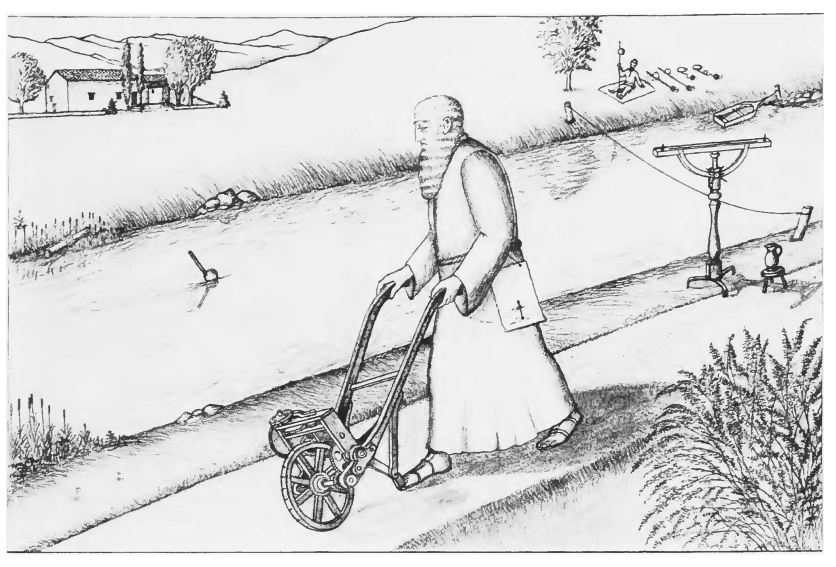

Figure 1. Leonardo da Vinci conducting experiments on the velocity-distribution in streams. Source: Water Current Meters by Frazier (1974).

\section{Origin of hydrology as a science}

Philosophical descriptions of the hydrological cycle were developed in ancient Asian and Middle Eastern civilizations, where large irrigation and flood protection works were carried out. The concept of hydrology was described in both the old Greek (e.g. Aristotle) and Roman (e.g. Marcus Vitruvius) cultures, where impressive water engineering projects were developed, such as aqueducts and bridges.

It was, however, not before the beginning of the 1500 s that a scientific approach to hydrology started to take off, albeit with a very slow starting speed. Leonardo da Vinci undertook physical experiments, e.g. measuring stream velocity, to support his advanced thoughts about hydrology (Pfister et al., 2009). In 1575, Bernard Palissy, based on observations in nature, claimed that springs originated from rain, and 100 years later, in 1674, Pierre Perrault measured the rainfall, runoff and drainage area of the Seine River and concluded that rainfall was enough to support springs and rivers. The pathways, however, were not correctly described. In 1686, Edme Mariotte supported the findings of Perrault by contributing infiltration experiments, relating them to precipitation regimes and developing better streamflow measurements. Around 1700, Edmond Halley published the results of evaporation measurements, thereby contributing significantly to closing the hydrological cycle. Nevertheless, it was not before 1802 that John Dalton became the first to give a complete and correct description of the cycle based on reliable observations (Dooge, 1974; Rodda, 2006). Thus, it took 300 years to lay the foundations for modern hydrology.

In 1738, Daniel Bernoulli published the equation for frictionless pipe flow. The 18th century brought further progress. Laminar pipe flow and turbulent river flow were described by, respectively, Gotthilf Hagen and Jean Poiseuille in 1840 and Antoine Chézy in 1776. During the 19th century, engineering became an important driver for further progress in hydrology.
The fundamental equation for groundwater flow was developed by Henry Darcy in 1856. Flow from urban catchments was addressed by introducing the time of concentration by Thomas Mulvany in 1850, leading to the rational method for peak flow design, and in 1883, Wenzel Rippl introduced the mass curve for reservoir design.

The first half of the 20th century brought additional basic development. A description of soil infiltration and saturation was provided by William Green and Gustav Ampt in 1911, while Weston Fuller introduced statistical frequency analysis in hydrology in 1914. Later fundamentals comprised the equation for unsaturated flow by Lorenzo Richards in 1931 and introduction of the unit hydrograph by Leroy Sherman in 1932. In 1935 Charles Theis presented the equation for the drawdown of the piezometric surface caused by pumping from a well, and finally, to conclude the 50 years, in 1948 Howard Penman developed an equation for estimating potential evaporation based on measured meteorological variables.

In the following, the main emphasis will be on the institutional development during the last centennial to support hydrology. For a more science-oriented description of the development, the reader is referred to Sivapalan and Blöschl (2017).

\section{The start of the association and the first period, 1922-1939}

At the general assembly of the IUGG in Rome in 1922, a delegate proposed a motion to form an additional section within the union to deal with the scientific problems in hydrology, such as "river-gauging, lake phenomena including seiches, run-off and evaporation, transport of material in suspension and in solution, glacier movement, etc." A committee was set up to give its opinion on the desirability of such a new activity. The committee gave favourable advice and proposed that the new organism should be named Section of Scientific Hydrology. The adjective "scientific" was added to distinguish the section's participants from the "charlatans and simpletons", who with the help of all sorts of rods tried to find water, calling themselves hydrologists, and also to make clear that the branch would not deal with the commercial exploitation of mineral waters. The first president was Edward Wade, who served from 1922 to 1933. (All subsequent presidents can be found at https://iahs.info/About-IAHS/Officers/ Past-Presidents/, last access: 10 December 2018).

One of the reasons presented in the proposal was that the new organization would allow incorporation of the International Glacier Commission (CIG) that was founded in 1894, but had almost ceased to exist because of the First World War. At the 1924 General Assembly of the IUGG in Madrid, the Hydrology Branch created a "Commission for Glaciers" with the mission to assemble and publish data relating to glaciers. The inclusion of CIG in the Commission for Glaciers was approved at the Prague Assembly in 1927. Since snow is- 


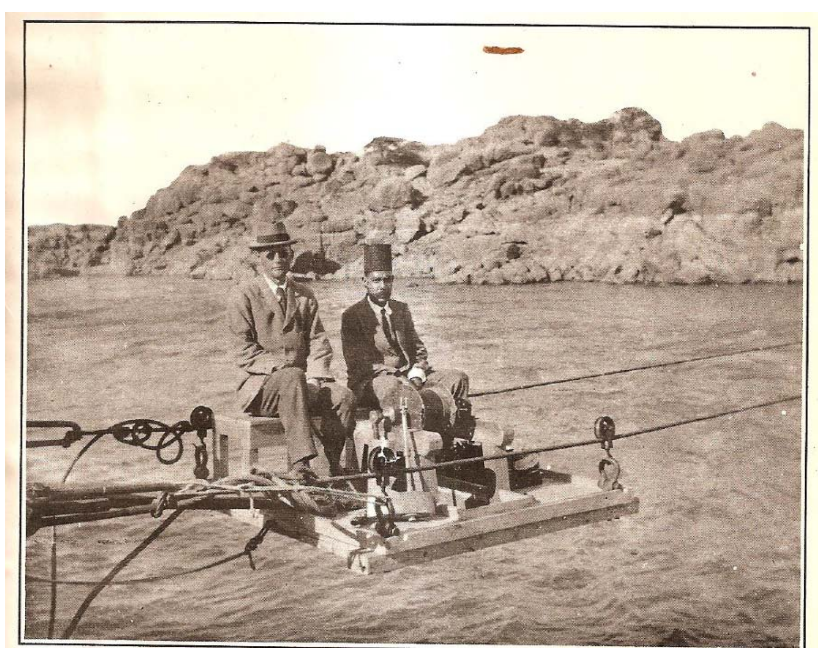

Figure 2. First IAHS President Edward Wade (left) taking flow measurements in the Nile River at Aswān in the early 1920s.

sues became of greater interest, a "Commission on Snow" was subsequently created in the early 1930s. At the Edinburgh Assembly in 1936, it was decided to amalgamate the two glaciological commissions into a new "Commission on Glaciers and Snow".

During the Madrid Assembly, a "Commission on Statistics" was constituted with the task of trying to bring some uniformity into the publication of hydrological data, and into the signs and symbols used. In addition, an effort was made to bring together data on the state of hydrology in different countries and to make an inventory of the water resources of these countries. The first publications of the branch comprised mostly national reports from this commission that served as background for two fundamental reports on, respectively, surface waters and subterranean waters. The scientists interested in this type of work were mostly hydraulic engineers, including teachers of hydraulics, who supplemented their teaching with the principles of hydrology. The report from the Madrid Assembly (IAHS, 1924) became the first in the Series of Proceedings and Reports, later known as Red Books. A complete list of the books is available at https://iahs.info (last access: 10 December 2018), where they can be either ordered (newer issues) or downloaded (older titles). During the 1933 Assembly in Lisbon, the branch was renamed the International Association of Scientific Hydrology (IASH).

Already in 1902, the first experimental basin study was initiated in the Emmental region of Switzerland (Whitehead and Robinson, 1993). In the 1930s, several additional studies were established assuming that in small experimental basins, it is easier to establish a water balance, and hydrological processes can be monitored and studied in detail. This methodology is generally accepted by the hydrological community as key to examining and observing small-scale hydrological phenomena.

The association began to cover an increasing number of hydrological disciplines, and new commissions on potamology, limnology, instruments and measurements, and subterranean waters were established. At the time of the Washington Assembly in 1939, the association had produced 27 publications in the series of Red Books. Because of the world war no IASH reports were published over the period 19391947. In 1935 the International Association of Hydraulic Research (IAHR) was created, which during the coming years led to a better distinction between hydrology and hydraulics.

\section{Recognition and expansion of IASH, 1948-1970}

Before World War II (1939-1945), hydrology, as it is understood today, was unknown to the public. Hydrology was not taught at universities as a separate subject. Fundamental aspects of it were included in such disciplines as physical geography and hydraulic engineering. However, during the period 1948-1970, hydrology became a generally recognized science of great significance for economic development. This had, of course, an enormous impact on the activities of IASH and its position in international scientific circles.

Post-war economic growth entailed a greater utilization of the natural resources of the Earth, water being one of the most important. Control and management of this resource became necessary in order to ensure adequate water supply for all sectors, together with flood forecasting and prediction. This could only be achieved by hydraulic works and structures, such as storage dams and reservoirs, diversion canals, embankments and groundwater recovery. The hydraulic design of these works required hydrological data extending over a sufficient number of years and sound knowledge of hydrological processes. This is especially true for the prediction of extreme events, such as major floods and serious droughts and their frequency of occurrence. Soon it was found that, in many cases, this sort of information was missing, and not only in developing countries. It was realized that the scarcity of hydrological information formed an obstacle to economic development, and that the water resources were limited even in humid zones. Thus hydrology, often mistakenly confused with water control, became an important discipline in the view of both decision makers and the public. This development lies behind the expansion of IASH in the period 1948 1970.

The meetings held during the General Assemblies of the IUGG in Oslo in 1948, in Brussels in 1951, and in Rome in 1954, were attended by an increasing number of participants of various backgrounds, such as hydraulic engineering, physical geography, geology, hydrometeorology and water management. A need was felt to organize more frequent meetings than would be possible within the framework of the union assemblies. The first meeting of this type was the 
Darcy Symposium in Dijon in 1956 on the occasion of the centenary of Darcy's law, where not only groundwater but also evaporation and floods were discussed. The frequency of these meetings, organized independently from the Union, increased, and in the 1960s, hardly a year passed by without one or even two symposia being convened under the primary responsibility of the association. All proceedings were published in the Red Books series. In 1948, León Tison from Belgium had assumed the duties of secretary general, and for more than 20 years, he served the association with great devotion and zeal. Tison succeeded in having the papers printed near his home at low cost and with small delays, so that the publications could be available at the meetings. He did all the secretarial work and the management of the affairs of the association, assisted by his wife, son and daughter.

The Red Books became widely read amongst the hydrological community and sold well. The series was supplemented by a series on snow and ice, co-edited with UNESCO, starting in 1967 and mainly containing information on the fluctuation of glaciers. Most of the papers of the Red Books series in the period since 1948 dealt with fields that would soon be called "applied hydrology" or "engineering hydrology". They were grouped according to a new division of the association into commissions on surface water, groundwater, land erosion, and snow and ice. The books also contributed to the drafting of hydrological textbooks and handbooks. Before the 1940s, the only book on hydrology in English was Beardmore's Manual of Hydrology, dating back to 1862 (Beardmore, 1862). In 1942, a monograph was published by Meinzer as one of the volumes of a series on Physics of the Earth (Meinzer, 1942), and in 1949 the first modern book on hydrology, Applied Hydrology by Linsley, Kohler and Paulhus (Linsley et al., 1949), was published to complement hydraulic engineering. Since then many other books have been published.

Publication of the quarterly Bulletin of the International Association of Scientific Hydrology, written in French and English, was started by Tison in 1956. It contained reports of association meetings, news and reports of assemblies, as well as some scientific articles. It is the oldest of the scientific journals dealing with hydrology. Around 1960, the United Nations and its specialized agencies initiated comprehensive intergovernmental cooperation within the field of water.

While the International Meteorological Organization, founded back in 1873, had undertaken some hydrological activities, it was not until it was transformed into a full intergovernmental organization as World Meteorological Organization (WMO) in 1950 that it looked seriously at including hydrology as one of its responsibilities. In 1955, WMO set up a committee to advise on the matter, which included Tison as secretary general of IASH. When, 6 years later, WMO's commission on the subject met for the first time, it elected Tison as its first vice president, thereby cementing the firm link between the association and WMO that has existed ever since. Of direct relevance to hydrology was the establishment in 1961 of a "Commission for Hydrometeorology", soon to be renamed the "Commission for Hydrology".

In 1965, a major programme was launched by UNESCO as the International Hydrological Decade (IHD), one of the three "fathers" being Tison. There was widespread acceptance of the IHD, as a large number of member states committed themselves to jointly carry out a well-defined programme of hydrological studies and research extending over the 10 years. This was a novelty in UNESCO and considered as an experiment. One of the conditions for the success of the venture was a good understanding and cooperation with IASH, being a non-governmental organization. There was some doubt within the association as to whether an entity like UNESCO, dealing with both exact and human sciences, would be the most appropriate place for discussion of practical problems of hydrology and water resources development. However, Tison realized that the IHD would enable important projects to be started that were beyond the potential of IASH. Cooperation would be facilitated by the fact that many representatives of member states in the coordinating council were active participants in IASH. Consequently, the cooperation became very effective. IASH helped formulate programmes and contributed to the activities of working groups, many of which were reported on in the early volumes of the bulletin. Proceedings of symposia were organized and published jointly. The association also produced monographs on various subjects with UNESCO, but particularly on the subjects of snow and ice. A similar relationship was established with WMO within its programme on operational hydrology, but on a less formal basis.

The same economic factors that promoted the expansion of IASH during the 1960s also led to a spectacular increase in the activities of other technical organizations in the field of water: hydraulic research, irrigation and drainage, large dams, water supply, water pollution, and so on. All of these associations were established after 1950. They included in their programmes many topics that were closely related to the activities of IASH without creating serious competition or duplication at that time. A body for mutual consultation and coordination of the scientific and technical organizations was established later.

In 1964, the International Council of Scientific Unions (ICSU), which included the IUGG, created a Committee on Water Research (COWAR) to promote contacts between the Scientific Unions dealing with water issues. This concerned, in the first place, the IUGG and the unions on geological sciences, biological sciences and the geographical sciences, all belonging to the ICSU family. In 1994, the committee was substituted by the "Scientific Committee on Water Research" (SCOWAR) focussing on applied global hydrology, improved access to hydrological data worldwide and global freshwater assessments based on scientific understanding.

In 1967, it was decided that IUGG general assemblies should be convened every 4 years. This decision was of little consequence for IASH as most of its activities took place 
outside the union assemblies. More serious was the increase in workload of the IASH Secretary General (13 symposia and 25 publications in the period 1965-1969). Sadly Léon Tison suffered a stroke in November 1970, when he was about to leave home to travel to New Zealand to participate in a symposium on Representative and Experimental Basins. His ill health threatened the very existence of the association.

\section{Transformation of IASH into IAHS and further growth, 1971-1981}

When Tison was forced to relinquish his position, it became obvious that because of the increasing workload and concurrent thrusts in hydrology, as well as the new ideas about the grouping of the water sciences, the association needed a change. Consequently, a revised set of Statutes and Bye-laws was brought into force at the Moscow General Assembly in 1971, including a change in the name to the International Association of Hydrological Sciences (IAHS). This change reflected the broadening of hydrology. Likewise, the number of Commissions was increased in response to the growth.

A new management structure was devised to cope with the increasing number of activities and the growing work load. A treasurer and an editor were appointed to operate alongside the secretary general. Annual meetings of the bureau of the association were instituted at this time, and more frequent meetings were held between the president and secretary general. An editorial office - later named the IAHS Press - was established at the Institute of Hydrology, Wallingford, UK, in 1971, and another milestone was reached when Red Book No. 100 appeared later that year as the proceedings of the symposium Mathematical Models in Hydrology Part 1 (IAHS, 1971). In 1972, the IASH Bulletin became the Hydrological Sciences Bulletin, now containing many more scientific papers alongside reports of IAHS symposia, etc. To provide news of the association, the secretary general started to publish a newsletter, which was initially circulated to IAHS national committees and to members of commissions and committees.

Another major development in the period 1971-1981 was the reorganization of the scientific structure of IAHS. This had to be enhanced because of the considerable progress that had been made in the analysis of hydrological processes. Before that, many basic questions could only be answered by applying semi-empirical approaches. Better understanding and a more sophisticated and a higher conceptual level were reached by the application of system analyses, stochastic methods and analysis of time series. These techniques of applied mathematics had been developed at least two decades earlier, but it took a long time before they became part of hydrological practice. The term "parametric hydrology" came into being. A "Committee on Mathematical Models" was set up, which later received the status of "Commission on Water Resources Relations and Systems". The title indicates that

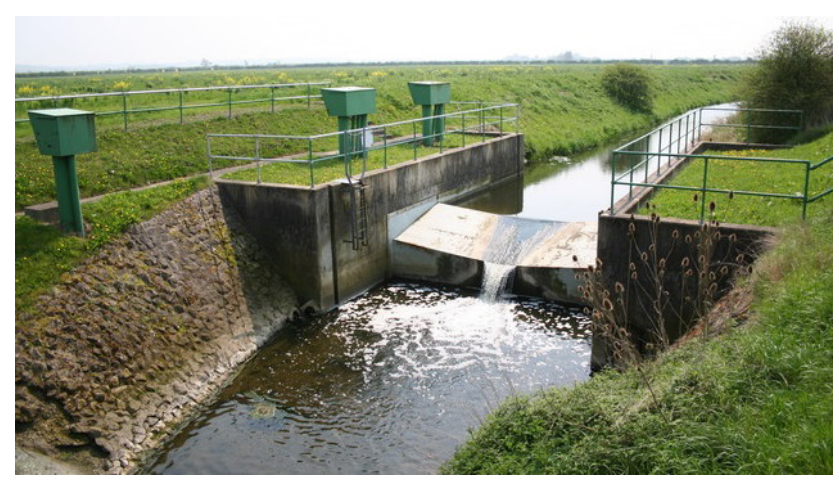

Figure 3. Brant Broughton gauging station, UK. Source: https://commons.wikimedia.org/wiki/File:Brant_Broughton_ Gauging_Station_-_geograph.org.uk_-_1057107.jpg (last access: 10 December 2018); photo: Richard Croft (CC BY-SA 2.0).

the field of work had been broadened. Likewise, the scope of the "Geochemical Commission" was changed during the Moscow Assembly in 1971, reflected in the new name "Commission on Water Quality".

When the IHD ended in 1974, the IAHS was one of the bodies that helped in the establishment of the permanent International Hydrological Programme (IHP) in UNESCO, a programme that was launched in 1975 . The association took part in the conference to mark the end of the decade (UNESCO/WMO, 1974), a conference that became the first of the 6-yearly Joint Conferences on Hydrology convened by UNESCO and WMO. During this period, the association continued the policy of pre-publishing Red Books prior to the symposium concerned, the cost of one copy of the proceedings being contained within each registration fee.

Generally, the development of hydrology after 1970 became heavily influenced by the emergence of computers. Hydrological modelling, first in the form of lumped, conceptual models, changed the scene. Later, the more computerdemanding so-called physically based hydrological models appeared. Since that time the hydrological science, like most other sciences, has developed with ever-increasing speed.

\section{IAHS in a changing environment, 1982-1999}

During the 1980s, environmental change and particularly climate change became more prominent on the research agenda. The development of improved global circulation models seemed a dominant trend, but for hydrologists their inability to simulate the hydrological cycle with any degree of verisimilitude, and the difficulties of incorporating land-atmosphere relations in them, were considerable impediments to progress. This was frustrating, because the increased power of computers and the advent of PCs provided opportunities in hydrology to simulate hydrological systems to a much higher degree of accuracy than before. These opportunities were stimulated by the development of new sen- 
sors on the ground and on satellites, to the extent that remote sensing became an important tool for hydrologists.

In response to these developments, IAHS started its own series of scientific assemblies, the first being held in Exeter in 1982. The assembly attracted over 500 participants, and the proceedings were published in six volumes, with nearly 1800 pages. For the Hamburg IUGG General Assembly in 1983, in contrast to the 1970s, the associations in the IUGG were able to arrange their own programmes within the assembly, and the IAHS attendance and programme benefited considerably as a result. Later during this period, the number of committees in IAHS was increased, and the joint IAHS/WMO GEWEX (Global Energy and Water Exchange) Committee was established. Both of these actions resulted from the widening of the role of the association in response to the scientific challenges arising. The purpose of the GEWEX Committee was in particular to establish a visibility and role for hydrologists in the burgeoning field of large-scale hydrometeorological field experiments.

In 1981, the association, in cooperation with UNESCO and WMO, started the annual award of a silver medal, known as the International Hydrology Prize, to hydrologists who had made an outstanding contribution to the science. The prize was first awarded to Léon Tison for the excellence of his contribution to the association and for his expertise in research and skills in teaching. The prize has been awarded every year since to hydrologists who have distinguished themselves and brought credit to the science. Further, the Hamburg Assembly in 1983 agreed to establish an annual award to mark the contributions of young scientists to the association. The award, which is in the form of a certificate and the sum of USD 1000, as well as a year's free subscription to the journal of the association, is known as the Tison Award. It is bestowed for the best paper or papers published by IAHS in the preceding 2 years. The Hamburg Assembly also set up the Hydrology 2000 Working Group, a group of young hydrologists, who reported to the Vancouver Assembly in 1987 on the probable state and shape of hydrology in the year 2000.

In 1983, the name of the bulletin was changed to the $\mathrm{Hy}$ drological Sciences Journal (HSJ), and from 1988 it was published bimonthly. The proceedings of the 1984 symposium on Hydrochemical Balances of Freshwater Systems (Eriksson, 1984) appeared as IAHS Publication No. 150. Only 13 years had elapsed since Publication No. 100 was published, compared to 37 years between Nos. 1 and 50. The IAHS Newsletter was put on a more formal basis towards the end of the 1980s, being produced 3 times a year, with a circulation of up to 1000 copies to members as well as to UNESCO and WMO. Two new series of publications were launched in 1989: IAHS Information in Chinese, containing selected papers from HSJ and IAHS Red Books, was published 4 times a year as a bridge between IAHS and Chinese hydrologists, and a series of Special Publications, also known as Blue Books, written at the invitation of the association. The first Blue Book, with the title Hydrological Phe- nomena in Geosphere-Biosphere Interactions (Falkenmark, 1989 ) is out of print; other titles include Leonardo Da Vinci's Water Theory: On the Origin and Fate of Water (Pfister et al., 2009), and the last one Changes in Flood Risk in Europe (Kundzewicz, 2012).

Specialized symposia continued to be organized by the commissions and committees of the association, independent of general assemblies and scientific assemblies, to the extent that in the early 1990s, seven or eight Red Books appeared in most years. Indeed, in 1991 IAHS Publication No. 200 appeared as the proceedings of the Fourth International Symposium on Land Subsidence (Johnson, 1991). UNESCO provided financial support for this publication as a contribution to the IHP, while a number of other Red Books received financial support from WMO and a range of bodies and sources during the 1990s. Since 1992, there have been a series of colloquia, known as the George Kovacs Colloquia, which have been organized jointly by IAHS and UNESCO for two or three days directly before the meetings of the Intergovernmental Council of the IHP. The association continues to work closely with both UNESCO and WMO. IAHS is represented at the Council and Commission meetings and in the subsidiary bodies of both. UNESCO and WMO are represented at the meetings of the IAHS Bureau and play influential parts in the affairs of the association.

Intense debates took place within the association around 1990. It was contended that water resources management, and in particular flood frequency modelling, should not be considered part of hydrology. This contention was opposed by other hydrologists, who pointed to the many achievements emerging from engineering approaches in hydrology. To limit hydrology to a pure geophysical science would be unreasonable and harm the association. No one really won the argument, and the disagreements were eventually reconciled. What was left by the crusade was a strengthening of the links between hydrology and geophysics.

Probably the most important IAHS initiative in support of the transfer of knowledge to developing countries was started in 1991, when the association's “Task Force for Developing Countries" (TFDC) commenced the mailing of Red Books and, in some cases also the HSJ, to libraries in nations in need (as defined by the United Nations). Over 70 addresses in financially disadvantaged countries were selected, covering many countries in all continents, on the understanding that the publications were made available to hydrologists and other scientists outside the recipient organization. The list of addresses has been revised a number of times subsequently, but the main thrust of this important initiative is continuing in the free online access to HSJ for about 70 addresses, as well as for IAHS members in the TFDC countries. 


\section{The transformation of IAHS, 2000-2018}

Two other heated debates within the association took place around the new millennium. One subject that involved much emotion was the wish of the glaciological community to leave IAHS in favour of a new cryosphere association within the IUGG. Snow and ice are integral parts of the hydrological cycle, and for that reason there was strong opposition in IAHS to accepting the new association. Again a compromise was achieved, which encompassed both a new glaciological association, the International Association of Cryospheric Science (IACS), in parallel to IAHS and a restructured commission on snow and ice hydrology within IAHS. Another subject was the suggestion that the commission structure should be abandoned and substituted by a purely projectdriven organization. This was strongly contradicted by many hydrologists, who, among other things, pointed to the benefit of the many symposia organized by the commissions and working groups. No one could deny that a project structure might attract young hydrologists and revitalize the association, but it should not be at the expense of the advantages provided by the commissions. In the end, a compromise was achieved leading to a cross-cutting decadal project on prediction in ungauged basins, named PUB.

At present, there are few continuous flow records for most of the world's rivers. Where these measurements are made, they are subject to measurement errors, particularly during floods and droughts, the records can be short and interrupted, the calibration of the gauging stations can be poor and old records are often lost. River gauging is subject to cutbacks in government funding and is vulnerable to strife. However, reliable knowledge of flow and other hydrological variables is vital for planning and operating water resources projects, for flood forecasting and prediction, combatting water pollution and a host of other purposes. Such knowledge is the very basis of sustainable development.

The continued lack of comprehensive understanding about what happens to the rain at the catchment scale when it hits the ground surface has led to a plethora of models being developed and used for predicting runoff. These models differ markedly in their model concepts and structure, their parameters, and the inputs they use. They also differ in terms of which dominant processes they represent and the scales at which they make predictions. Most models are developed by different individuals and groups, with different disciplinary backgrounds; they benefit from local observations, experiences and practices that are influenced by local climate conditions and catchment characteristics. Consequently, they tend to have unique features not applicable in other places: every hydrological research group around the world seemingly studies a different object, their local catchment. The net result has been considerable fragmentation, "a cacophony" and a dissipation of effort that is not conducive to further advances.
In this context, the IAHS Decade on Predictions in Ungauged Basins was launched in 2003, aimed at achieving major advances in the capacity to make predictions in ungauged basins, through harnessing improved understanding of climatic and landscape controls on hydrological processes. The vision of PUB was to help a transformation "from cacophony to a harmonious melody". One of the clear tasks that the PUB initiative set out to achieve was to address the fragmentation of modelling approaches through comparative evaluation: "classify model performances in terms of time and space scales, climate, data requirements and type of application, and explore reasons for the model performances in terms of hydrological insights and climate-soil-vegetationtopography controls."

The decade was a great success in giving new momentum to IAHS. It attracted many young researchers around the world and created a forum for cooperation of the commissions. It succeeded in developing models to better predict availability of water in diverse climatic and economic circumstances and water-use settings, and to better forecast and predict floods and droughts in basins and regions in which there has been little or inadequate data on which to base models. The PUB decade resulted in three major publications: a review summary article in HSJ, "A decade of Predictions in Ungauged Basins (PUB) - A review" (Hrachowitz et al., 2013), and two books, Runoff Prediction in Ungauged Basins - Synthesis across Processes, Places and Scales (Blöschl et al., 2013), and Putting Prediction in Ungauged Basins into Practice (Pomeroy et al., 2013). These publications combine advancing the predictive capability and fundamental understanding of hydrological processes with making the findings relevant to the needs of societies in basins of all scales. The PUB initiative has brought together scientists, practitioners and policy makers from around the world and from many organizations, including UNESCO, in a cooperative effort.

Given the role of the IAHS as a leader in international hydrology, a new series of Benchmark Papers in Hydrology was launched in 2006 as a major effort for diffusion of the most important ideas in hydrology to libraries, institutes and individuals, interpreting the hydrological sciences in the broadest sense. The IAHS commission presidents served as editorial board members to the series. Each volume contains an Introduction prepared by the specialist volume editor together with commentaries; articles from the key papers of the 20th century are fully reproduced (exceptionally in part). In total, nine such volumes were published, starting with Streamflow Generation Processes (Beven, 2011), a selection of 31 papers spanning the period 1933-1984, commencing with Horton's early papers on infiltration and on maximum groundwater levels. The last book in the series Paleohydrology (Baker, 2014), provided a strong focus on palaeofluvial processes, especially palaeoflooding.

The success of the PUB decade made a follow-up essential. Consequently, IAHS launched, for the period 2013 
2022, a new scientific decade entitled Panta Rhei - Everything Flows (Montanari et al., 2013). The initiative is dedicated to research activities on change in hydrology and society. The purpose of the Panta Rhei initiative is to reach an improved interpretation of the processes governing the water cycle by focusing on their shifting dynamics in connection with rapidly changing human systems. The practical aim is to improve our capability to make predictions of water resources dynamics to support sustainable societal development in a changing environment. The concept implies a focus on hydrological systems as a changing interface between environment and society, whose dynamics are essential for determining water security, human safety and development, and for setting priorities for environmental management. The Panta Rhei scientific decade will devise innovative theoretical blueprints for the representation of processes including change and will focus on advanced monitoring and data analysis techniques. An interdisciplinary path will be sought by bridging with socio-economic sciences and geosciences in general.

The Panta Rhei decade has three clear objectives:

1. Understanding. This has always been the essence of hydrology as a science. Improving our knowledge of hydrological systems and their responses to changing environmental (including anthropogenic) conditions, and in particular variability and indeterminacy, is a key step in deciphering change and the interaction with society. Special attention is being devoted to complex systems, such as mountain areas, urban areas, alluvial fans, deltas and intensive agricultural areas, and to the specification of new measurement and data analysis techniques, which will allow the development of new understanding of co-evolution processes.

2. Estimation and prediction. This is closely related to understanding and is the essence of hydrologic engineering and hydrological applications, embracing flood risk mitigation and water resources management. This objective includes estimation of design variables under change and uncertainty assessment, which are crucial to support risk evaluation.

3. Science in practice. This signifies the aim to include humans in the study of hydrological systems and, therefore, to achieve an iterative exchange between science, technology and society. Science in practice is science for people. It is, therefore, relevant to science (both fundamental and applied) and relevant to water technology. It includes policy-making and implementation. The relevance of hydrology to society implies the identification of societal needs for water - for its various uses - as well as the threats that water poses in terms of flooding, land degradation and droughts. Here, we need a shift in paradigms of modern water management based on equities between demand- and supply-driven activities.

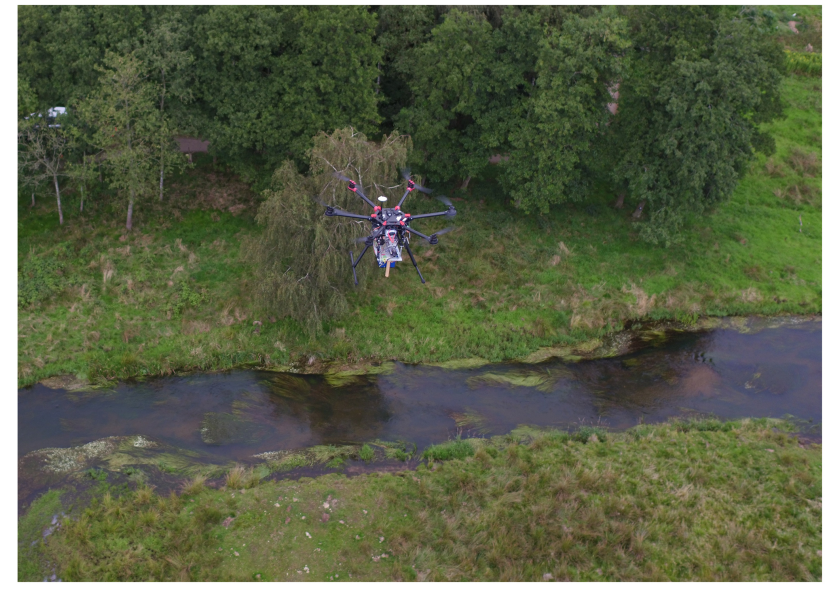

Figure 4. Flow measurements using a drone. Flight campaign by Sune Yde Nielsen, Henrik Karmisholt Grosen (Drone Systems.DK), Christian Josef Köppl and Filippo Bandini (DTU Environment).

The continuous fall in the number of river flow gauging stations and the decline of precipitation networks are challenging in hydrology. To circumvent this, new observational methods based on advanced technology are entering the scene. There is growing use of remotely sensed data from satellites, aircraft surveillance, weather radar and now from unmanned aerial vehicles (UAVs, i.e. drones). This trend will continue and is expected to provide new opportunities to hydrologists.

From 2014, IAHS, UNESCO and WMO decided to award two international prizes each year in place of the International Hydrology Prize; these were denoted the Dooge Medal and the Volker Medal, named after two of the early recipients of the International Hydrology Prize.

With the success of the updated IAHS website and online news, the free IAHS Newsletter was discontinued in 2014, and in 2015, the last Red Book was printed. In addition to their scientific value, the Red Books recorded the progress of the association and its science in a way unmatched by other IUGG associations and by the IUGG itself. For many years, the Red Books sales had provided an income for the association, but with the new era of electronic publishing, this was no longer the case. As electronic publishing is the preferred medium for proceedings, it was decided to stop printing books, while continuing to publish the series electronically as the Proceedings of the International Association of Hydrological Sciences (PIAHS), with unbroken numbering and with free online access (and print on demand only). IAHS Publication No. 368 on Remote Sensing and GIS for Hydrology and Water Resources (Chen et al., 2015) was the last Red Book published in-house by IAHS. 


\section{Conclusions: the current state of IAHS}

The IAHS Bureau governs the association; it consists of the president, the president-elect or immediate past president, three vice presidents, the secretary general, the treasurer, the editor-in-chief and presidents of the scientific commissions in existence at the time, as well as the chair of the International Association of Hydrological Sciences Limited. The final authority of the association in all matters of administration and finance is vested in the plenary administrative session of the association. It consists of the above persons plus one voting delegate from each adhering country. The company IAHS Ltd. deals, i.a., with the IAHS publishing programme, including the arrangements for the scientific journal. IAHS offers free membership and has currently 7000 members distributed throughout almost 200 countries.

With the activities of 10 commissions, 4 working groups and an ongoing, vibrant scientific decade, Panta Rhei, IAHS is in excellent shape. The commissions and working groups are as follows:

- International Commission on Surface Water (ICSW)

- International Commission on Groundwater (ICGW)

- International Commission on Continental Erosion (ICCE)

- International Commission on Snow and Ice Hydrology (ICSIH)

- International Commission on Water Quality (ICWQ)

- International Commission on Water Resources Systems (ICWRS)

- International Commission on the Coupled LandAtmosphere System (ICCLAS)

- International Commission on Tracers (ICT)

- International Commission on Remote Sensing (ICRS)

- International Commission on Statistical Hydrology (ICSH)

- IAHS Working Group on Panta Rhei (everything flows)

- IAHS Working Group on Education in Hydrology

- IAHS Working Group on MOXXI (Measurements \& Observations in the 21 st Century)

- IAHS Working Group on CandHy (Citizen and Hydrology).

The work of the IAHS Task Force for Developing Countries continues. Hydrology in Wallingford takes care of the peer-review process of HSJ (which now has 3 co-editors and 48 associate editors) and its publication in partnership with the publishing company Taylor \& Francis; the administration of the proceedings series (PIAHS), published by Copernicus; and provides support to the Bureau, maintaining the IAHS website (https://iahs.info/, last access: 10 December 2018) through the IAHS Executive Secretary.

The International Association of Hydrological Sciences is a coherent and well-integrated organization across all its different activities. Perhaps this is the reason why the wisdom of changing from "science" to "sciences" in 1971 has recently been challenged. Hydrology is today a well-defined science in its own right and not a collection of different sciences. A discussion is ongoing, and perhaps we will soon see a renaming of the association to, for example, International Hydrology Association (IHA). This, however, is a future decision.

Competing interests. The authors declare that they have no conflict of interest.

Special issue statement. This article is part of the special issue "The International Union of Geodesy and Geophysics: from different spheres to a common globe" (https://www.hist-geo-space-sci. net/special_issue996.html). It is not associated with a conference.

Acknowledgements. The contributions to the IAHS history by Arthur Askew, Henny Colenbrander, Christophe Cudennec, Pierre Hubert, Hubert Savenije, the late Adriaan Volker, Frances Watkins and Gordon Young are greatly acknowledged. Thanks are also due to the large number of hydrologists who have aided and promoted the association since its inception in 1922. The paper has been written with due consideration of Volker and Colenbrander (1995), Rodda (1999, 2012) and Cudennec et al. (2013).

Edited by: Jo Ann Joselyn

Reviewed by: one anonymous referee

\section{References}

Baker, V. R.: Paleohydrology, IAHS Benchmark Papers in Hydrology No. 9, International Association of Hydrological Sciences, Wallingford, UK, 2014.

Beardmore, N.: Manual of Hydrology, Waterlow and Sons, London, UK, 1862.

Beven, K. J.: Streamflow Generation Processes, International Association of Hydrological Sciences, Wallingford, UK, IAHS Benchmark Papers in Hydrology No. 1, 2011.

Blöschl, G., Sivapalan, M., Wagener, T., Viglione, A., and Savenije, H. (Eds.): Runoff Prediction in Ungauged Basins - Synthesis across Processes, Places and Scales, Cambridge University Press, UK, 2013.

Chen, Y., Neale, C., Cluckie, I., Su, Z., Zhou, J., Huang, Q., and $\mathrm{Xu}, \mathrm{Z}$.: Remote Sensing and GIS for Hydrology and Water Resources, International Association of Hydrological Sciences, Wallingford, UK, IAHS Publ. No. 368, 2015. 
Cudennec, C., Young, G., and Savenije, H.: Cooperation on water sciences and research, In: Reaching Water Security through Cooperation, UNESCO Publication FF 2405, 322-324, 2013.

Dooge, J. C. I.: The development of hydrological concepts in Britain and Ireland between 1674 and 1874, Hydrological Sciences Bulletin, 19, 279-302, 1974.

Eriksson, E. (Ed.): Hydrochemical Balances of Freshwater Systems, International Association of Hydrological Sciences, Wallingford, UK, IAHS Publ. No. 150, 1984.

Falkenmark, M.: Hydrological Phenomena in Geosphere-Biosphere Interactions, International Association of Hydrological Sciences, Wallingford, UK, IAHS Special Publications No. 1, 1989.

Frazier, A. H.: Water Current Meters in the Smithsonian Collections of the National Museum of History and Technology, Smithsonian Studies in History and Technology, 28, 1-95, https://doi.org/10.5479/si.00810258.28.1, 1974.

Hrachowitz, M., Savenije, H. H. G., Blöschl, G., McDonnell, J. J., Sivapalan, M., Pomeroy, J. W., Arheimer, B., Blume, T., Clark, M. P., Ehret, U., Fenicia, F., Freer, J. E., Gelfan, A., Gupta, H. V., Hughes, D. A., Hut, R. W., Montanari, A., Pande, S., Tetzlaff, D., Troch, P. A., Uhlenbrook, S., Wagener, T., Winsemius, H. C., Woods, R. A., Zehe, E., and Cudennec, C.: A decade of Predictions in Ungauged Basins (PUB) - A review, Hydrol. Sci. J., 58, 1198-1255, 2013.

IAHS: Assemblée Generale de Madrid - General Assembly, International Association of Hydrological Sciences, Wallingford, UK, IAHS Publ. No. 1, 1924.

IAHS: Mathematical Models in Hydrology - Part 1, International Association of Hydrological Sciences, Wallingford, UK, IAHS Publ. No. 100, 1971.

Johnson, A. I. (Ed.): Proceedings of the Fourth International Symposium on Land Subsidence, International Association of Hydrological Sciences, Wallingford, UK, IAHS Publ. No. 200, 1991.

Kundzewicz, Z. W. (Ed.): Changes in flood Risk in Europe, International Association of Hydrological Sciences, Wallingford, UK, IAHS Special Publications No. 10, 2012.

Linsley, R. K, Kohler, M. A., and Paulhus, J. L. H.: Applied hydrology, McGraw-Hill, New York, 1949.

Meinzer, O. E. (Ed.): Hydrology, in: Physics of the Earth, Vol. 9, McGraw-Hill, New York, 1942.
Montanari, A., Young, G., Savenije, H. H. G., Hughes, D., Wagener, T., Ren, L. L., Koutsoyiannis, D., Cudennec, C., Toth, E., Grimaldi, S., Blöschl, G., Sivapalan, M., Beven, K., Gupta, H., Hipsey, M., Schaefli, B., Arheimer, B., Boegh, E., Schymanski, S. J., Di Baldassarre, G., B. Yu, B., Hubert, P., Huang, Y., Schumann, A., Post, D. A., Srinivasan, V., Harman, C., Thompson, S., Rogger, M., Viglione, A., McMillan, H., Characklis, G., Pang, Z., and Belyaev, V.: Panta Rhei - Everything Flows": Change in hydrology and society - The IAHS Scientific Decade 2013-2022, Hydrol. Sci. J., 58, 1256-1275, 2013.

Pfister, L., Savenije, H. H. G., and Fenicia, F.: Leonardo da Vinci's Water Theory: On the origin and fate of water, International Association of Hydrological Sciences, Wallingford, UK, IAHS Special Publication No. 9, 2009.

Pomeroy, J. W., Whitfield, P. H., and Spence, C. (Eds.): Putting Predictions of Ungauged Basins into Practice, Canadian Water Resources Association \& International Association of Hydrological Sciences, Canada, 2013.

Rodda, J. C.: Promoting international co-operation in learning - the role of the International Association of Hydrological Sciences, in: Proc. Int. Symp., edited by: Van der Beken, A., Mihailescu, M., Hubert, P., and Bogardi, J., The Learning Society and the Water-environment, 374-379, 1999.

Rodda, J. C.: On the British contribution to international hydrology - a historical perspective, Hydrol. Sci. J., 51, 1177-1193, 2006.

Rodda, J.: History of IAHS, available at: https://iahs.info/ About-IAHS/History-of-IAHS.do (last access: 10 December 2018), 2012.

Sivapalan, M. and Blöschl, G.: The growth of hydrological understanding, Water Resour. Res., 53, 8137-8146, 2017.

UNESCO/WMO: Records of the International Conference on the Results of the International Hydrological Decade and on the Future Programmes in Hydrology, Vol. I-V, United Nations Educational, Scientific and Cultural Organization \& World Meteorological Organization, Paris, available at: http://unesdoc.unesco. org/images/0001/000155/015542eb.pdf (last access: 10 December 2018), 1974.

Volker, A. and Colenbrander, H.: History of IAHS pre-1996, available at: https://iahs.info/About-IAHS/History-of-IAHS/ History-by-.do (last access: 10 December 2018), 1995.

Whitehead, P. G. and Robinson, M.: Experimental basin studies an international and historical perspective of forest impacts, J. Hydrol., 145, 217-230, 1993. 